\section{Living conditions and access to health services by Bolivian immigrants in the city of São Paulo, Brazil}

\author{
Condições de vida e acesso a serviços de saúde \\ de imigrantes bolivianos no centro da cidade \\ de São Paulo, Brasil
}

\section{Condiciones de vida y acceso a servicios de salud por los inmigrantes bolivianos en el centro de la ciudad de São Paulo, Brasil}

\begin{abstract}
Bolivian immigrants in Brazil experience serious social problems: precarious work conditions, lack of documents and insufficient access to health services. The study aimed to investigate inequalities in living conditions and access to health services among Bolivian immigrants living in the central area of São Paulo, Brazil, using a cross-sectional design and semi-structured interviews with 183 adults. According to the data, the immigrants tend to remain in Brazil, thus resulting in an aging process in the group. Per capita income increases the longer the immigrants stay in the country. The majority have secondary schooling. Work status does not vary according to time since arrival in Brazil. The immigrants work and live in garment sweatshops and speak their original languages. Social networks are based on ties with family and friends. Access to health services shows increasing inclusion in primary care. The authors conclude that the immigrants' social exclusion is decreasing due to greater access to documentation, work (although precarious), and the supply of health services from the public primary care system.
\end{abstract}

Emigration and Immigration; Social Conditions; Health Services Accessibility
Cássio Silveira ${ }^{1}$

Nivaldo Carneiro Junior 1

Manoel Carlos Sampaio de Almeida Ribeiro 1 Rita de Cássia Barradas Barata 1

\section{Resumo}

Os bolivianos no Brasil têm problemas sociais evidentes: inserção precária no trabalho, falta de documentos e necessidades em saúde. O estudo teve por objetivo conhecer as desigualdades geradas pelas condições de vida e de acesso aos serviços de saúde entre os imigrantes bolivianos na cidade de São Paulo, Brasil. Foi feito um estudo transversal com 183 adultos, subdivididos pelo tempo de residência no país, com aplicação de questionário semiestruturado. Os dados evidenciaram a permanência e o envelhecimento desses imigrantes. A renda per capita é ascendente conforme o tempo no país; na formação escolar predomina o nível médio; o tempo de permanência no Brasil não altera a situação de trabalho; trabalham e vivem nas confecções e falam suas linguas de origem. Predominam as redes sociais familiares e de amigos. O acesso aos serviços de saúde ocorre com progressiva inclusão em ações de atenção primária. Concluímos que há um processo de exclusão decrescente, que acontece pelo acesso à documentação, ao trabalho, ainda que precário, e pela oferta de serviços da rede pública de atenção primária em saúde.

Migração Internacional; Condições Sociais; Acesso aos Serviços de Saúde 


\section{Introduction}

The presence of Bolivian immigrants in downtown São Paulo, Brazil, has raised a debate on social inclusion, especially access to health services. Historical evidence points to the economic attraction exerted by the work market as the main factor for the contingent of Bolivian immigrants that came to (and stayed in) São Paulo since the mid-20th century, with an important increase since the 1980s due to expansion of the Brazilian textile industry and economic difficulties in the immigrants' home country 1,2 .

Current estimates of the number of immigrants are imprecise, ranging from 80 to 200 thousand Bolivians. The city of São Paulo concentrates some $40 \%$ of this Bolivian immigrant population. Still, a demographic transition can already be seen with the "aging" that has occurred in parallel to the arrival of new Bolivian immigrants 3 .

As these immigrants come to and stay in São Paulo, they are exposed to hardships along the way and in their adaptation to a new living situation in a foreign country, often including precarious work relations, unhealthy housing, the language barrier, and racism, discrimination, and prejudice in public institutions. A complex set of situations thus shape various vulnerabilities, with evidence of loss of social rights and social protection 4,5,6,7.

The immigrants constitute a heterogeneous social group, with different ethnic backgrounds and a diverse range of social concepts and practices produced in their original cultural contexts. This poses challenges for the design and implementation of social policies, especially in health care 2,6,8,9,10,11.

This aim of this study was to discuss a set of data on living conditions and access to health services among Bolivian immigrants living in downtown São Paulo, based on a household survey in 2008 that included the Bolivian immigrants, a group of homeless individuals, and Brazilian nationals with and without social vulnerability. The purpose is to encourage the debate on the social inclusion of this group of immigrants, contributing new knowledge on their living conditions and providing support for inclusive and equitable policies for social protection.

\section{Methods}

The data on Bolivian immigrants analyzed in this study were collected in a household survey in 2008 with a cross-sectional design. The study focused on the downtown area of São Paulo, based on a sample of adults in three segments: Brazilian nationals with fixed domiciles, homeless Brazilians (living on the street), and Bolivian immigrants.

The sample was calculated as 1,500 individuals for the three segments in the survey, considering a difference of $10 \%$ in the proportion of fair or poor self-rated health, estimated with data from the National Household Sample Survey by the Brazilian Institute of Geography and Statistics 12, with an alpha error of $5 \%$ and power of $80 \%$.

The census tracts in the neighborhoods comprising the city center were classified according to the São Paulo Social Vulnerability Index developed by the Seade Foundation (Foundation of the State Data Analysis System) 13. Five hundred households were selected randomly in census tracts without social vulnerability, 500 households in tracts with social vulnerability, 250 homeless Brazilians, and 250 Bolivian immigrants. More details on the methodology are provided elsewhere 11 .

For the Bolivian immigrants, the focus of this article, a probabilistic sample of 250 individuals was obtained from the registry of the Family Health Strategy (ESF) the Dr. Alexandre Vranjac Barra Funda Academic Health Center (CSEBFAV), São Paulo Mercy Hospital (ISCMSP), where 980 Bolivian immigrants are registered. This sample framework was chosen due to the difficulty in access to the group of immigrants in general.

Ten interviewers who spoke Spanish were trained for the survey. Difficulties in access to the households, mostly garment sweatshops where the immigrants live and work, reduced the originally planned number of interviews. The final sample was 183 Bolivian adults, including 96 men $(53 \%)$ and 87 women $(47 \%)$.

The data collection instrument (a semistructured questionnaire) was prepared and pretested, demographic data (sex, age, ethnic group, and conjugal status), economic data (work, income, and schooling), immigration (time living in Brazil, documents, and language spoken), social network (support network, family, friends, and social events), and access to health services (health plan, health service used, and utilization in the previous 30 days).

The data were analyzed and presented according to time living in Brazil. The data were also compared to those obtained in the same survey for Brazilian nationals in census tracts with social vulnerability. The comparisons used the chisquare test with an alpha error of $5 \%$.

The study project was approved by the Institutional Review Board of the São Paulo Mercy Hospital, registration number n. 061/07. All the interviewees were informed verbally and in writ- 
ing as to the study objectives, after which they signed the informed consent form. All necessary precautions were taken to ensure confidentiality for the study subjects and the content of their interviews.

\section{Results}

Of the initially selected sample of 250 immigrants, the survey obtained information on 183 individuals. Of these, 94 (52\%) reported living in Brazil for more than 5 years. Only $9 \%$ reported living in Brazil for less than a year.

Table 1 shows the immigrants' socio-demographic characteristics according to time living in Brazil. The data show that the group consists mainly of young people and adults of both sexes who were not living with partners at the time of the interview, with a mean monthly income of 1 to 3 times the minimum wage (despite having secondary schooling), using Spanish or an indigenous language on a daily basis, and legally documented to live in Brazil.

Table 1 also shows significant differences for all the variables except gender and schooling between recent immigrants (living up to 5 years in the country) and established immigrants (6 years or more). The established group is older, has a higher proportion of individuals with income greater than 3 times the minimum wage, individuals that speak Portuguese, and those with legal resident documents. The group of recent immigrants shows a higher proportion of individuals with partners.

Table 2 shows the data on employment conditions, with significant differences according to time living in Brazil. The majority have paid work,

Socio-demographic characteristics of Bolivian immigrants in the city of São Paulo, Brazil, according to time living in the country, 2008.

\begin{tabular}{|c|c|c|c|c|c|c|c|}
\hline \multirow[t]{2}{*}{ Socio-economic characteristics } & \multicolumn{2}{|c|}{$0-5$ years } & \multicolumn{2}{|c|}{$6-20$ years } & \multicolumn{2}{|c|}{ Total } & \multirow[t]{2}{*}{ p-value } \\
\hline & $\mathrm{n}$ & $\%$ & $\mathbf{n}$ & $\%$ & $\mathbf{n}$ & $\%$ & \\
\hline Age (years) & & & & & & & $<0.001$ \\
\hline $0-29$ & 60 & 72.3 & 26 & 28.0 & 86 & 48.9 & \\
\hline $30-49$ & 19 & 22.9 & 50 & 53.8 & 69 & 39.2 & \\
\hline$\geq 50$ & 4 & 4.8 & 17 & 18.3 & 21 & 11.9 & \\
\hline Sex & & & & & & & 0.901 \\
\hline Male & 46 & 52.3 & 50 & 53.2 & 96 & 52.7 & \\
\hline Female & 42 & 47.7 & 44 & 46.8 & 86 & 47.3 & \\
\hline Living with spouse/partner & & & & & & & $<0.001$ \\
\hline Yes & 39 & 44.3 & 18 & 19.1 & 57 & 31.3 & \\
\hline No & 49 & 55.7 & 76 & 80.9 & 125 & 68.7 & \\
\hline Income in minimum wages * & & & & & & & $<0.001$ \\
\hline$<1$ & 20 & 25.3 & 2 & 13.3 & 22 & 13.3 & \\
\hline $1-3$ & 48 & 60.8 & 57 & 63.3 & 105 & 63.3 & \\
\hline 3 & 11 & 13.9 & 28 & 23.5 & 39 & 23.5 & \\
\hline Schooling & & & & & & & 0.944 \\
\hline Primary & 16 & 18.2 & 18 & 19.4 & 34 & 18.8 & \\
\hline Secondary & 58 & 65.9 & 63 & 67.7 & 121 & 66.9 & \\
\hline University & 4 & 4.5 & 3 & 3.2 & 7 & 3.9 & \\
\hline Other & 10 & 11.4 & 9 & 9.7 & 19 & 10.5 & \\
\hline \multicolumn{8}{|l|}{ Language spoken at home } \\
\hline Portuguese & 0 & - & 11 & 11.7 & 11 & 6.0 & 0.001 \\
\hline Spanish and others ** & 88 & 100.0 & 83 & 88.3 & 171 & 94.0 & \\
\hline \multicolumn{8}{|l|}{ Documented } \\
\hline Yes & 41 & 47.7 & 88 & 93.6 & 129 & 71.7 & $<0.001$ \\
\hline No & 45 & 52.3 & 6 & 6.4 & 51 & 28.3 & \\
\hline
\end{tabular}

* Monthly minimum wage: BRL 415.00 (approximately U\$200);

** Quechua, Aymara, or Guarani. 
Employment characteristics of Bolivian immigrants and Brazilian nationals with social vulnerability living in São Paulo, Brazil, 2008.

\begin{tabular}{|c|c|c|c|c|c|}
\hline \multirow[t]{2}{*}{ Characteristics } & \multicolumn{2}{|c|}{ Bolivian immigrants } & \multicolumn{2}{|c|}{ Brazilians with social vulnerability } & \multirow[t]{2}{*}{ p-value } \\
\hline & $n$ & $\%$ & $\mathrm{n}$ & $\%$ & \\
\hline \multicolumn{6}{|l|}{ Employment status } \\
\hline Paid employment & 158 & 86.3 & 353 & 68.7 & $<0.001$ \\
\hline Unemployed & 5 & 2.7 & 64 & 12.5 & \\
\hline \multicolumn{6}{|l|}{ Type of employment status } \\
\hline Employed with signed work papers & 7 & 3.8 & 151 & 43.8 & $<0.001$ \\
\hline Employed without signed work papers & 40 & 21.9 & 71 & 20.6 & \\
\hline Self-employed without own business & 84 & 45.9 & 95 & 27.5 & \\
\hline Self-employed with own business & 20 & 10.9 & 26 & 7.5 & \\
\hline Employer & 8 & 3.3 & 2 & 0.6 & \\
\hline
\end{tabular}

which is more frequent among the Bolivian immigrants as compared to Brazilian nationals in conditions of social vulnerability. However, the group of Bolivian immigrants shows a significantly lower proportion with legal work papers and a higher proportion of self-employed individuals without businesses. Meanwhile, the Bolivian immigrants show a higher proportion of employers as compared to the Brazilian nationals in conditions of social vulnerability.

Social networks are important for establishing and maintaining care among the immigrants (Table 3). The data show that in relation to the variables used to evaluate support from relatives and friends, the situation of Bolivian immigrants does not differ strikingly from that of Brazilian nationals in conditions of vulnerability, except for participation in groups or social activities.

Table 4 shows data on access to and use of health services and private health insurance coverage among Bolivian immigrants. The data are displayed according to time in Brazil and in comparison to Brazilian nationals with social vulnerability. The proportion of Bolivian immigrants with private health insurance is negligible and significantly smaller than that of Brazilians with vulnerability. Health insurance coverage does not differ between the two groups of immigrants (recently-arrived versus established).

Although both groups of immigrants predominantly use primary health services, there are significant differences according to time living in Brazil in relation to treatment in pharmacies (more common among recent immigrants) and the use of emergency services (more common among immigrants established in Brazil for more than 5 years). As compared to Brazilian nationals with vulnerability, Bolivian immigrants report more use of primary health care services and less use of outpatient clinics. As for treatment in pharmacies or emergency departments, the group of immigrants established in Brazil for more than 5 years show a similar pattern to that of Brazilian nationals in situations of vulnerability.

Table 5 shows the data on self-rated health and use of health services in the 30 days prior to the interview for Bolivian immigrants and Brazilian nationals in situations of vulnerability. The groups do not differ significantly in use of health services in the previous month $(p=0.396)$, although more Bolivian immigrants rate their health as poor, compared to Brazilians in situations of vulnerability. At any rate, both groups make extensive use of health services. These variables do not differ between the two groups of immigrants according to time living in Brazil.

As shown in Table 4, the data show practically the same distribution for place of care.

\section{Discussion}

Different theories have been produced to explain migratory processes, some with greater emphasis on economic factors affecting the relations between state and market in encouraging and controlling the immigration of workers 14 , while other theories focus on more comprehensive social structures, identifying a multiplicity of paths for individual spatial and socioeconomic mobility. Finally, other authors seek to analyze migratory movements in all their economic and ethnic complexity and in the formation of social networks 15 .

More recent authors have ruled out the idea of individual decision-making in migratory 
Social network of Bolivian immigrants and Brazilian nationals with social vulnerability living in São Paulo, Brazil, 2008.

\begin{tabular}{|c|c|c|c|c|c|}
\hline \multirow[t]{2}{*}{ Social network } & \multicolumn{2}{|c|}{ Bolivian immigrants } & \multicolumn{2}{|c|}{ Brazilian with social vulnerability } & \multirow[t]{2}{*}{ p-value } \\
\hline & $\mathbf{n}$ & $\%$ & $\mathrm{n}$ & $\%$ & \\
\hline \multicolumn{6}{|c|}{ Receive support when sick? } \\
\hline Yes & 142 & 80.7 & 457 & 89.1 & 0.002 \\
\hline No & 34 & 19.3 & 51 & 10.9 & \\
\hline \multicolumn{6}{|c|}{$\begin{array}{l}\text { Receive help to care for children, elderly, or persons } \\
\text { with disability? }\end{array}$} \\
\hline Yes & 98 & 65.3 & 324 & 75.8 & 0.078 \\
\hline No & 52 & 34.7 & 118 & 24.2 & \\
\hline \multicolumn{6}{|c|}{$\begin{array}{l}\text { Have relatives and friends that live nearby and can be } \\
\text { visited? }\end{array}$} \\
\hline Yes & 119 & 65.4 & 343 & 71.8 & 0.133 \\
\hline No & 63 & 34.6 & 135 & 28.2 & \\
\hline \multicolumn{6}{|c|}{$\begin{array}{l}\text { In case of problems, receive support from friends and } \\
\text { family? }\end{array}$} \\
\hline Yes & 127 & 70.8 & 363 & 75.0 & 0.290 \\
\hline No & 53 & 29.4 & 121 & 25.0 & \\
\hline \multicolumn{6}{|c|}{ Attend groups or social activities? } \\
\hline Yes & 27 & 14.9 & 111 & 22.8 & 0.032 \\
\hline No & 154 & 85.1 & 375 & 77.2 & \\
\hline
\end{tabular}

Table 4

Access to health services by Bolivian immigrants and Brazilian nationals with social vulnerability living in São Paulo, Brazil, according to time in the country, 2008.

\begin{tabular}{|c|c|c|c|c|c|c|c|c|c|}
\hline & \multicolumn{2}{|c|}{$0-5$ years } & \multicolumn{2}{|c|}{$6-20$ years } & \multicolumn{2}{|c|}{ Total } & \multicolumn{2}{|c|}{ Brazilians with social vulnerability } & \multirow[t]{2}{*}{ p-value } \\
\hline & $\mathbf{n}$ & $\%$ & n & $\%$ & $\mathrm{n}$ & $\%$ & n & $\%$ & \\
\hline Yes & 4 & 4.5 & 3 & 3.2 & 7 & 3.8 & 127 * & 26.1 & $<0.001$ \\
\hline No & 84 & 95.5 & 91 & 96.8 & 175 & 96.2 & 359 & 73.9 & \\
\hline \multicolumn{10}{|c|}{ Health service used when sick } \\
\hline Primary care & 52 ** & 65.8 & 64 & 66.3 & 113 & 66.1 & 143 * & 31.4 & $<0.001$ \\
\hline Outpatient clinic & 4 & 5.1 & 7 & 7.6 & 29 & 17.0 & 137 & 30.1 & 0.020 \\
\hline Pharmacy & 14 & 17.7 & 4 & 4.3 & 18 & 10.5 & 34 & 7.5 & \\
\hline Emergency service & 9 & 11.4 & 20 & 21.7 & 11 & 6.4 & 141 & 31.0 & \\
\hline
\end{tabular}

* Comparison between Bolivian immigrants and Brazilian Nationals with social vulnerability;

** Comparison within group of Bolivian immigrants according to time living in Brazil

processes, incorporating into the analysis the decisions made in the family setting and social networks. Social ties unite original communities to common destinations through the formation of effective units of migration, shaping sets of individuals linked by friendship, kinship, and common work experiences. The networks end up shaping two paths for migrants: on the one hand, risks are mitigated by the interpersonal re- lations in which information on the trajectories circulates; on the other, various types of exploitation and risks of violence towards individuals and groups can exist within the networks themselves $16,17,18$.

For other authors, the analysis of the phenomenon of migration is based on the assumption of the existence of multiple relations among immigrants, both in their places of origin and in 
Self-rated health, use of health services in the previous 30 days, and place of care for Bolivian immigrants and Brazilian nationals with social vulnerability living in São Paulo, Brazil, 2008

\begin{tabular}{|c|c|c|c|c|c|}
\hline & \multicolumn{2}{|c|}{ Bolivian immigrants } & \multicolumn{2}{|c|}{ Brazilians with social vulnerability } & \multirow[t]{2}{*}{ p-value } \\
\hline & $\mathbf{n}$ & $\%$ & $\mathbf{n}$ & $\%$ & \\
\hline Good & 49 & 27.2 & 298 & 61.2 & $<0.001$ \\
\hline Poor & 131 & 72.8 & 189 & 38.8 & \\
\hline \multicolumn{6}{|c|}{ Use of health service in previous 30 days } \\
\hline Yes & 75 & 41.2 & 181 & 37.2 & 0.396 \\
\hline No & 107 & 58.8 & 305 & 62.8 & \\
\hline \multicolumn{6}{|l|}{ Place of care } \\
\hline Emergency service & 10 & 13.5 & 28 & 15.6 & $<0.001$ \\
\hline Hospital & 9 & 12.2 & 32 & 17.8 & \\
\hline Clinic or physician's office & 2 & 2.7 & 42 & 23.3 & \\
\hline Primary health care service & 43 & 58.1 & 56 & 31.1 & \\
\hline
\end{tabular}

their country of destination. Immigrants are thus referred to as "transmigrants", since they maintain family, economic, social, organizational, religious, and political relations among themselves in both their homeland and their destination. They expand relations between the local and global spheres and establish social processes that cross geographic, cultural, and political borders. This reinforces the criticism of analytical categories with a more traditional approach, classifying migrants in three categories: "temporary", "returnees", and "permanent". The authors propose overcoming this perspective by refusing to see contradictions in the immigrants' contact with the societies that receive them, promoting living contexts that can be achieved without forgoing the relations established in their life processes, or even without changing the lifestyles, habits, and values shaped in their original cultures 19 .

However, analyses of migratory processes are not limited to the formation of networks. These analytical possibilities can be expanded to include the notion of a transnational space in which migratory processes occur. This space is permeated by phenomena resulting from internationalization of production and reorganization of the world economy. From this perspective, the circulation of workers is one of several flows that produce intense movement in social relations at the international level (also including the circulation of capital, merchandises, services, and information).

In this context, migration enhances the creation of spaces in the market for organized out- sourcing and the provision of opportunities for the establishment of small family-based household businesses characterized mainly by piecework. This internationalization process leads to the organization of a clandestine network of labor relations, structured in an informal market and with deleterious consequences for individuals, families, and groups 20 .

The theoretical premises outlined above on the migratory process indicate at least three approaches to explain and frame the phenomenon. First, the formation of social networks allows mapping the set of elements constituting the basis of support for the migratory process in the country of destination. Second, international flows of workers are characteristic of globalization and advanced capitalism, with the maintenance of labor relations based on exploitation. Third, the same processes that engender migrations end up shaping the establishment of persons and families in dynamic socio-cultural contexts. These contexts reveal cultural contrasts or even processes of social division in the societies that receive the immigrants, and at the same show the creation of relational arrangements in the work process, in the search to meet their needs, and in subsistence in the receiving societies, but without a loss of identities, ties to their place of origin, and especially without a break in the social and cultural structures that link and strengthen the intertwining of relational life for immigrants.

The socio-demographic data of the Bolivian immigrants in this study suggest that the migra- 
tory flow to São Paulo is an economic part of the flows of workers to cities with major potential to attract labor. Time elapsed since the immigrants' arrival, age, gender balance, and level of schooling suggest that these individuals probably migrated in search of work opportunities.

Living with a spouse or partner was a predominant characteristic among more recent immigrants, suggesting that staying longer in the country is associated with breakdown in conjugal relations.

Although per capita income improves over time, the situation for immigrants cannot be considered good, even when compared to Brazilian nationals in situations of vulnerability. Their level of schooling in their home country points to a high percentage of individuals with secondary schooling, which should provide for better positions in the work market. Even so, the market does not totally assimilate them, for various possible reasons: the language barrier, which can be a limiting factor for occupying job positions, or the existence of a magnet for this migratory flow towards work in the textile industry, specifically garment-making.

In terms of inclusion or exclusion in the society of destination, time living in the country does not change either the immigrants' work situation or the percentage that communicate in Portuguese on a daily basis. The majority work and survive by establishing relations within the group of Bolivian immigrants themselves, in which they form networks to exchange information and access opportunities for survival 17,18.

Data on participation in the work market deserve a more in-depth analysis in light of the theoretical approach to advanced capitalism, which reorganizes production processes, encouraging and legitimating household or small-group work strategies, making labor relations and work conditions precarious, as evidenced in the literature review 20 . Interestingly, despite a significant increase in legally documented individuals among those living in Brazil for more than 5 years, the work conditions did not change, at least in relation to the type of employment relationship, suggesting that language may be an important issue in their precarious inclusion in the work market.

Confinement in the domestic and work space, combined with communications barriers and lack of legal documentation, can lead to segregation and fail to contribute to the expansion of participation in broader social networks. However, the comparison to Brazilian nationals in situations of social vulnerability suggests that the issue is complex; beyond the immigrants' condition, it may be associated with the more precarious social inclusion of both groups.
The vulnerabilities of migrant individuals and groups, which can be exemplified by the risks in interpersonal relations, work situations, and situations of social exclusion motivated by relations based on prejudices, the existence of discriminatory acts (sometimes institutionalized), and often the extermination of individuals as a phenomenon in various societies 7 are also translated as a more precarious health situation.

The complexity of the phenomena of illness and other health problems that can involve immigrants, such as domestic violence, work-related diseases, and mental health problems, among others, poses challenges for the health sector. The fragmentation of health sector policies that reduces the effectiveness of health interventions for other segments of society particularly affects these groups of immigrants, given the specific conditions in which the care for their needs is provided 7,21,22,23,24.

Although the survey did not obtain information on self-reported disease history, the accumulation of disadvantages and health risks in the group of immigrants can be measured by the prevalence of negative self-rated health (the combination of fair, bad, and very bad) as compared to Brazilian nationals in the same neighborhood in situations of social vulnerability. The Bolivians' self-rated health is worse than expected for a group of young people and adults with relatively high schooling.

This study's data show that the immigrants depend almost exclusively on the Brazilian Unified National Health System (SUS) for their health care, since private insurance coverage is insignificant and mean income does not allow out-ofpocket payment.

Unlike some developed countries in which health services have interpreters to assist health care for foreigners, in Brazil (and specifically in São Paulo) the public system lacks qualified personnel for this purpose, thereby raising an important barrier to proper care.

Although public health programs traditionally include legal devices and organizational structures to deal with health problems on land, air, and maritime borders, so-called "travelers' health" focuses more on passengers' transit than on migratory movements.

Solving immigrants' health problems should include a vision of society and social policy based on universal rights and the hope for a world without borders. Thus, organization of the health sector would allow recognizing the immigrants' need for universal, comprehensive, and equitable access to services. Meanwhile, the health care supply should be guaranteed for immigrants in structured services that allow access and recep- 
tion of groups with health concepts and practices that are usually different from the socio-cultural context in the country of destination. This view of the process would allow the formulation of health policies that would contemplate the moments in the migratory process and its specificities and needs, identifying preexisting needs in the countries of origin and in the migratory move itself and the risks involved until the arrival and settlement in new living situations in the country of destination 7 .

In many cases, the lack of documents prevents or hinders access to health services. Various European countries receive large flows of immigrants and open their health system partially to the undocumented. Even in these cases the actions are insufficient to meet the immigrants' needs. Their rights, sometimes minimized, sometimes denied, and other times partially accepted in these countries, end up constituting attempts rather than solutions to challenges posed by social processes in the context of transnationality 25 .

In South America, migratory processes are associated with precarious living and health conditions among a major portion of immigrants in their countries of origin, as well as with the heavy social inequality on the continent. In Brazil, as in other countries, the health sector has difficulty absorbing these demands. Even with the multilateral agreements established between Latin American countries in the last decade, such initiatives have failed to take the form of inclusive social policies that would facilitate access to health services and promote the maintenance of health care for immigrants already established in the country. These initiatives are generally limited to sanitary and epidemiological surveillance and the control and regulation of the immigration of health professionals, thus representing isolated and fragmented measures 26,27.

The precarious work and living conditions of Bolivian immigrants in the city of São Paulo have an analogous situation in Buenos Aires, Argentina. The opportunities offered by a changing market in a context of global flexibilization of labor relations point to the casualization of work and the limited visibility of a population contingent that lives and works in sweatshops 28 . In this context, health conditions become worse, making immigrants more susceptible to illness. Their experience with illness, the set of preexisting diseases in their country of origin, and their tradition with health care all form a complex scenario of problems that can remain invisible to the public sector 29,30,31,32.

The city of São Paulo had its health services incorporated into the SUS later than the rest of
Brazil 33. However, the last decade has witnessed a concern for the inclusion of part of the Bolivian immigrants into health services, particularly in primary care through the ESF. The hiring of Bolivian community health workers for the family health teams has been a step forward for primary care, seeking to overcome the language barrier. However, the social actions targeting immigrants have failed to achieve more comprehensive results in social inclusion 34 . Isolated action by nongovernmental organizations such as the Immigrants' Mission (affiliated with the Catholic Church) and other community associations that publish information or refer immigrants to services are also part of this reality 35 .

As for access to health services, the data indicate gradual inclusion of the immigrants. However, the Bolivians interviewed in this study were already users of the health service, which could represent a selection bias, thus skewing our results. The study shows a significant difference in time since arrival in Brazil, in relation to familiarity with (and use of) different types of health services, especially primary care, which is used more by immigrants that have lived longer in the country, and in the use of care in health care establishments other than pharmacies 34 .

Finally, the study shows low coverage by private health plans. Limited access to these plans indicates precarious employment relations, since for most workers private health coverage is part of a set of benefits associated with formal work. Thus, lower coverage by health plans is one more indication of precarious inclusion in the work market.

\section{Final remarks}

The borders separating social groups in complex societies are marked by more fluid limits in relation to belonging to society; such borders are thus more difficult to observe in research. This implies the need to explain relations as a whole and not merely the more immediate socioeconomic characteristics identified in the group of immigrants. Zaluar 36 refers to "shadowy areas" in relations between groups, or more obscure spaces that should be studied to produce more indepth analyses of the established relations and the consequences for the lives of these groups. Established ties, relations shaped through work, and networks of solidarity developed in family networks that allow the construction of more efficient forms of protection (although limited by the incapacity of the immigrant group to solve all its problems) are some key examples in the constitution of the phenomenon of immigration. 
Progress in knowledge on Bolivians and other immigrants should contribute to the debate on their socio-demographic characteristics and inclusion, based on more in-depth analyses and the formulation and implementation of inclusive and equitable policies for social protection, both in terms of the design and especially in the actions ${ }^{4}$. Such studies provide the opportunity to view the existence of the immigrant groups in their totality, capturing part of the migratory process and including them in the set of social relations marked by situations of permanent vulnerability.

The case of Bolivian immigrants has revealed a series of weaknesses in work relations and a lack of more comprehensive policies, sensitive to the group's particular needs. Situations that often expose immigrants to vulnerability can be exemplified by precarious work relations and possible family breakdown, many times marked by relations based on physical, sexual, and symbolic violence. These are common facts in the daily lives of Bolivian immigrants in São Paulo, already evidenced by the health services working in downtown São Paulo.

In conclusion, we infer that immigration of Bolivians to the city of São Paulo appears to point the way to a process of both exclusion and inclusion based on the contradictions raised by precarious work on the one hand and the establishment of social health policies at the local level, especially access to primary care.

However, we reaffirm the need to produce more studies with the necessary scope and depth to prove or challenge the above conclusions. Studies are needed that produce knowledge that allow researchers and social policymakers to grasp a contemporary and complex social reality that is still largely unknown.

\section{Resumen}

Los bolivianos en Brasil tienen evidentes problemas sociales: inserción precaria en el trabajo, falta de documentos y necesidades de salud. El estudio tiene como objetivo identificar las desigualdades generadas por las condiciones de vida y el acceso a los servicios de salud entre los inmigrantes bolivianos en São Paulo, Brasil. Se realizó un estudio transversal con 183 adultos, dividido por el tiempo de residencia en el país, con la aplicación de un cuestionario semi-estructurado. Los datos mostraron la permanencia de estos inmigrantes y el envejecimiento. El ingreso per cápita aumenta con el tiempo que están en el país, la formación educacional domina la enseñanza secundaria, la duración del tiempo en el país no cambia la situación laboral, trabajan y viven en los talleres textiles y hablan sus lenguas nativas. Predominan las redes sociales de familiares y amigos. El acceso a los servicios de salud ocurre vía la inclusión progresiva en acciones de atención primaria. Llegamos a la conclusión de que existe un proceso de exclusión decreciente, derivado del acceso a la documentación, al trabajo, aunque precario, y la prestación de servicios en la atención primaria de la salud pública.

Migración Internacional; Condiciones Sociales; Accesibilidade a los Servicios de Salud

\section{Contributors}

C. Silveira contributed to the design, planning, data analysis and interpretation, preparation of the draft, and approval of the final version. N. Carneiro Junior collaborated in the design, planning, data analysis and interpretation, elaboration of the critical revision of the content, and approval of the final version. M. C. S. A. Ribeiro collaborated in the design, data analysis and interpretation, and approval of the final version. R. C. B. Barata collaborated in the design, data analysis and interpretation, elaboration of the critical revision of the content, and approval of the final version.

\section{Acknowledgements}

The authors wish to thank CNPq for funding the research project. 


\section{References}

1. Silva SA. A migração dos símbolos: diálogo intercultural e processos identitários entre os bolivianos em São Paulo. São Paulo Perspect 2005; 19:77-83.

2. Silva SA. Bolivianos em São Paulo: entre o sonho e a realidade. Estud Av 2006; 20:157-70.

3. Souchaud S. A imigração boliviana em São Paulo. In: Ferreira AP, Vainer C, Póvoa Neto H, Santos MO, organizadores. A experiência migrante: entre deslocamentos e reconstruções. Rio de Janeiro: Garamond; 2010. p. 72-95

4. Carneiro Jr. N, Silveira C. Organização das práticas de atenção primária em saúde no contexto dos processos de exclusão/inclusão social. Cad Saúde Pública 2003; 19:1827-35.

5. Carneiro Júnior N, Andrade MC, Luppi CG, Silveira C. Organização de práticas de saúde equânimes em atenção primária em região metropolitana no contexto dos processos de inclusão e exclusão social. Saúde Soc 2006; 15:30-9.

6. Hernández-Quevedo C, Jiménez-Rubio D. A comparison of the health status and health care utilization patterns between foreigners and the national population in Spain: new evidence from the Spanish National Health Survey. Soc Sci Med 2009; 69:370-8.

7. Zimmerman C, Kiss L, Hossain M. Migration and health: a framework for 21 st century policy-making. PLoS Med 2011; 8:e1001034.

8. Wolff H, Stalder H, Epiney M, Walder A, Irion O, Morabia A. Health care and illegality: a survey of undocumented pregnant immigrants in Geneva. Soc Sci Med 2005; 60:2149-54.

9. Madi MCC, Cassanti AC, Silveira C. Estudo das representações sociais sobre gestação em mulheres bolivianas no contexto da atenção básica em saúde na área central da cidade de São Paulo. Saúde Soc 2009; 18:67-71.

10. Sass N, Figueredo Junior AR, Siqueira JM, Silva FRO, Sato JL, Nakamura MU, et al. Maternal and perinatal outcomes in Bolivian pregnant women in the city of São Paulo: a cross-sectional casecontrol study. Rev Bras Ginecol Obstet 2010; 32: 398-404.

11. Barata RB, Ribeiro MC, Cassanti AC; Grupo do Projeto Vulnerabilidade Social no Centro de São Paulo. Social vulnerability and health status: a household survey in the central area of a Brazilian metropolis. Cad Saúde Pública 2011; 27 Suppl 2:S164-75.

12. Instituto Brasileiro de Geografia e Estatística. Pesquisa Nacional por Amostra de Domicílios - PNAD 2003 http://www.ibge.gov.br/home/estatistica/ populacao/trabalhoerendimento/pnad2003/coe ficiente_brasil.shtm (accessed on 10/May/2012).

13. Fundação Sistema Estadual de Análise de Dados. Índice Paulista de Vulnerabilidade Social, 2008. http://www.seade.gov.br/projetos/ipvs/ (accessed on 10/May/2012).

14. Muniz JO. Um ensaio sobre as causas e características da migração; 2002 http://www.ssc.wisc. edu/ jmuniz/ensaio_migracao.pdf (accessed on 10/May/2012)
15. Sasaki EM, Assis GO. Teorias das migrações internacionais. In: XII Encontro Nacional da ABEP; outubro 2000 http://www.abep.nepo.unicamp.br/ docs/anais/pdf/2000/Todos/migt16_2.pdf (accessed on 10/May/2012).

16. Massey DS. Dimensions of the new immigration to the United States and the prospects for assimilation. Ann Rev Sociol 1981; 7:57-85.

17. Massey DS, Arango J, Hugo G, Kouaouci A, Pellegrino A, Taylor JE. Theories of international migration: a review and appraisal. Population and Development Review 1993; 19:431-66.

18. Guilmoto CZ, Sandron F. The internal dynamics of migration networks in developing countries. Population: An English Selection 2001; 13:135-64.

19. Glick-Schiller N, Basch L, Szanton Blanc C. Transnationalism: a new analytic framework for understanding migration. In: Glick-Schiller N, Basch L, Szanton Blanc C, editors. Toward a transnational perspective on migration. New York: New York Academy of Sciences; 1992. p. 1-24.

20. Sassen S. As cidades na economia mundial. São Paulo: Studio Nobel; 1998.

21. Ahonen EQ, Benavides FG, Benach J. Immigrant populations, work and health: a systematic literature review. Scand J Work Environ Health 2007; 33:96-104

22. Choy JY. Contextual effects on health care access among immigrants: lessons from three ethnic communities in Hawaii. Soc Sci Med 2009; 69:1261-71.

23. Gushulak BD, MacPherson DW. Health aspects of the pre-departure phase of migration. PLoS Med 2011; 8:e1001035.

24. Steel Z, Liddell BJ, Bateman-Steel CR, Zwi AB. Global protection and health impact of migration interception. PLoS Med 2011; 8:e1001038.

25. Karl-Trummer U, Novak-Zezula S, Metzler B. Access to health care for undocumented migrants in the EU: a first landscape on NowHereLand. Eurohealth 2010; 16:13-6.

26. Dias JCP, Schofield CJ. Controle da transmissão transfusional da doença de Chagas na Iniciativa do Cone Sul. Rev Soc Bras Med Trop 1998; 31:373-83.

27. Giovanella L, Guimarães L, Nogueira VMR, Lobato LVC, Damacena GN. Saúde nas fronteiras: acesso e demandas de estrangeiros e brasileiros não residentes ao SUS nas cidades de fronteira com países do MERCOSUL na perspectiva dos secretários municipais de saúde. Cad Saúde Pública 2007; 23:S251-66.

28. Rizek CS, Georges I, Silva CF. Trabalho e imigração: uma comparação Brasil-Argentina. Lua Nova 2010 79:111-42.

29 Stuyft PV, Muynck A, Schillemans L, Timmerman C. Migration, acculturation and utilization of primary health care. Soc Sci Med 1989; 29:53-60.

30. Anderson JM. Ethnicity and illness experience: ideological structures and the health care delivery system. Soc Sci Med 1986; 22:1277-83. 
31. Goldberg A. Sociocultural factors in the health care process of patients with tuberculosis, of Vaccarezza Institute Hospital. Rev Argent Salud Pública 2010; 1:13-21.

32. Goldberg A. Abordaje antropológico comparativo en torno a la incidencia del Chagas y la tuberculosis en inmigrantes bolivianos residentes en Barcelona y Buenos Aires, respectivamente. EA Journal of Medical Humanities \& Social Studies of Science and Technology 2010; 1(3). http://www.ea-journal. com/art1.3/Abordaje-antropologico-comparativochagas-tuberculosis.pdf.

33. Alves Sobrinho EJM. São Paulo de volta ao Brasil e à Constituição. In: Sousa MF, Mendes A, organizadores. Tempos radicais da saúde em São Paulo: a construção do SUS na maior cidade brasileira. São Paulo: Editora Hucitec; 2003. p. 25-30.
34. Carneiro Junior N, Oliveira RLS, Jesus CH, Luppi CG. Migração, exclusão social e serviços de saúde: o caso da população boliviana no centro da cidade de São Paulo. BIS - Boletim do Instituto de Saúde 2011; 13:177-81.

35. Silveira C, Carneiro Junior N, Marsiglia RMG, organizadores. Projeto inclusão social urbana: "nós do centro". Metodologia de pesquisa e de ação para inclusão social de grupos em situação de vulnerabilidade no centro da cidade de São Paulo. São Paulo: Fundação Arnaldo Vieira de Carvalho; 2009.

36. Zaluar A. Exclusão e políticas públicas: dilemas teóricos e alternativas políticas. Revista Brasileira de Ciências Sociais 1997; 12(35). http://www.scielo. br/scielo.php?pid=S0102-69091997000300003\&script=sci_arttext.

Submitted on $02 /$ Aug/2012

Final version resubmitted on $07 / \mathrm{Mar} / 2013$

Approved on 01/Apr/2013 